\title{
Identification of Leaf Based Physiological Markers for Drought Susceptibility during Early Seedling Development of Mungbean
}

\author{
Puspendu Dutta1,2, Pintoo Bandopadhyay ${ }^{3}$, A. K. Bera1 \\ ${ }^{1}$ Department of Plant Physiology, Faculty of Agriculture, Bidhan Chandra Krishi Viswavidyalaya, Mohanpur, Nadia, India \\ ${ }^{2}$ Present Address: Department of Seed Science and Technology, Faculty of Agriculture, Uttar Banga Krishi Viswavidyalaya, Pundibari, \\ Cooch Behar, India \\ ${ }^{3}$ Department of Agronomy, Faculty of Agriculture, Bidhan Chandra Krishi Viswavidyalaya, Mohanpur, Nadia, India \\ Email: pdutta.pph@gmail.com
}

How to cite this paper: Dutta, P., Bandopadhyay, P. and Bera, A.K. (2016) Identification of Leaf Based Physiological Markers for Drought Susceptibility during Early Seedling Development of Mungbean. American Journal of Plant Sciences, 7, 1921-1936. http://dx.doi.org/10.4236/ajps.2016.714176

Received: July 30, 2016

Accepted: September 27, 2016

Published: September 30, 2016

Copyright $\odot 2016$ by authors and Scientific Research Publishing Inc. This work is licensed under the Creative Commons Attribution International License (CC BY 4.0).

http://creativecommons.org/licenses/by/4.0/ (c) $\underset{\mathrm{EY}}{\text { (i) Open Access }}$

\begin{abstract}
Drought is a recurrent phenomenon in many of the countries. Moisture stress during seedling stage is very critical in determining the establishment of the crop and its further development and yield. Identifying drought tolerance mechanism and physiological markers of drought susceptibility is this crop during seedling stress would be useful tool in future genetic manipulation programme to establish drought tolerance in this crop. Thus the present study aimed for quickly identifying reliable physiological markers for drought susceptibility through evaluation of physiological and biochemical changes in leaves of two contrasting mungbean (Vigna radiata L. Wilczek) cultivars i.e. K 851 (drought tolerant) and PDM 84-139 (drought susceptible) during seedling development. A range of four external water potentials (i.e. -1.0 , $-2.0,-3.0$ and -4.0 bars), besides glass distilled water as control ( 0.0 bar), was used. Parameters like leaf area, relative leaf water content, chlorophyll content, chlorophyll stability indices in both the cultivars were decreased with the increasing magnitude of stress. By and large phenols and ascorbic acid content were increased with the stress level but the trend was not consistent. A steady rise in proline, hydrogen peroxide content and lipid peroxidation was found with water stress. Out of two cultivars tested, drought tolerant cultivar $\mathrm{K} 851$ was better in leaf water balance and higher accumulation of phenols, proline and ascorbic acid than PDM 84-139. The correlation study indicated lipid peroxidation and $\mathrm{H}_{2} \mathrm{O}_{2}$ content as valuable physiological markers for screening of drought susceptibility.
\end{abstract}

\section{Keywords}

Leaf, Lipid Peroxidation, Mungbean, Physiological Markers, Water Stress 


\section{Introduction}

The abiotic stresses such as drought, low or high temperature, salinity, flooding, shade or high light levels, inorganic nutrient imbalance, man-made toxic compounds and oxidative stress [1] cause losses worth hundreds of million dollars each year due to reduction in crop productivity and crop failure. Among the environmental stress water stress is the second contributor of yield reduction after disease [2]. Water is required in a number of physical, physiological and biochemical processes of the plant. Water stress is the most widely operative stress that causes heavy loss in productivity of crops every year. In general, drought stress induces an array of morphological, physiological, biochemical, and molecular responses associated with growth, development, and economic yield of a crop [3].

Seedling growth that determines the crop establishment and stands in the field is considered to be most critical for raising a successful agricultural crop, as they determine the crop stand density and establishment of the resultant crop, especially under abiotic stresses [4].

Among the pulse crops, Mungbean (Vigna radiata L. Wilczek) has a special importance of intensive crop production due to its short growth period. It is predominantly cultivated as rainfed crop under Indian context and as a result, the crop has become sudden victim of drought at various phases of growth and development. The crop is potentially useful for improving cropping pattern as it can be grown as a cash crop due to its rapid growth and early maturing characteristics. Drought problems for mungbeans are worsening with the rapid expansion of water stressed areas of the world including 3 billion people by 2030 [5]. Crop yield of mungbean is more dependent on an adequate supply of water than any other single environmental factor [6]. Therefore, cultivation of drought-tolerant mungbean varieties plays a vital role in the future research. The physiological screening and the cultivar identification are establishing theoretical and practical foundation for drought-tolerant breeding of mungbean.

Leaves are the most sensitive part of plant to drought and at the same time, they are the most essential organ for the manufacture of food. Drought stress leads to water deficit in leaf tissues, thus affecting many physiological processes with ultimate consequences on the growth and development of the plant. Changes in morpho-physiological parameters like leaf rolling, reduction in leaf area, stomatal closure, decreased stomatal conductance, reduced chlorophyll content, limited internal $\mathrm{CO}_{2}$ concentration, reduced photosynthesis [7] and metabloic parameters like changes in solute concentration, lipid peroxidation, glutathione and ascorbate levels are very critical, and have been reported to be involved in either tolerance and/or avoidance under water stress [8] [9]. Though chlorophyll fluorescence had been used an indicator parameter for assessment of drought survival in recent times but there was no association between chlorophyll fluorescence and yield under drought stress [10]. Drought tolerance is seen in almost all plants but its extend varies from species to species and even within species [11]. Breeders instinctively look for new sources of variations when attempting to improve plants, 
but tolerance to drought stress is very complex, due to the intricate of the interactions between stress factors and various molecular, biochemical and physiological phenomena affecting plant growth [12].

Current insight indicates that tolerance of plants to drought involves multifaceted physiological paradigms with great variation of stress tolerance at intra-specific and inter-specific levels leading to difficulties in identifying single criteria which could effectively be used as selection target. Rather it would be most meaningful, if physiological and biochemical stress markers for individual species are determined since most of the above indices have limited application for selection of drought tolerance at early growth stages [13]. Hence, present study of comparative account of morpho-physiological parameters and biochemical constituents in leaves of two contrasting mungbean cultivars would identify the basic causes of drought injury and probable mechanism behind the tolerance to water stress. The correlation analyses among the various parameters would be worthy to quickly identify leaf based reliable physiological markers for drought susceptibility, and the generated information would be handy in future genetic manipulation programme to establish drought tolerance in this crop.

\section{Materials and Methods}

\subsection{Seed Materials}

Mungbean (Vigna radiata L. Wilczek) cultivars, K 851 (drought tolerant) and PDM 84-139 (drought susceptible) were selected from a laboratory screening [14] with sixteen mungbean cultivars collected from the Project Coordinator, All Indian Coordinated Research Project on MULLaRP, Indian Institute of Pulses Research, Kalyanpur, Kanpur, U.P., India. Seeds of uniform size were surface sterilized with $0.1 \%$ (w/v) $\mathrm{HgCl}_{2}$ for two minutes and then washed thoroughly with glass distilled water. A range of four external water potentials (viz. $-1.0,-2.0,-3.0$ and -4.0 bars) were prepared by using polyethylene glycol (PEG) 6000 as per methods of Michel and Kaufmann [15].

\subsection{Seedling Development}

Surface sterilized seeds of mungbean cultivars were soaked in different PEG solutions separately for five hours. Pre-soaked seeds were then allowed to develop seedlings in respective PEG solutions for six days under in-door laboratory conditions following standard glass plate technique [16]. Surface sterilized seeds treated similarly with glass distilled water served as control (0.0). All observations were recorded from six-day-old seedlings, as they survive better up to six days under this cultural condition utilizing cotyledonary reserve food materials, and beyond which seedlings enter into senescence. On sixth day, seedlings were removed from glass plate under respective solutions, and leaves were separated and the following morpho-physiological and biochemical studies were conducted with randomized primary leaf samples from the treated and control seedlings of the two cultivars. For dry weight whole seedlings were taken separately from another set of experiment and then dried in a hot air oven at $80^{\circ} \mathrm{C} \pm 2{ }^{\circ} \mathrm{C}$ for 72 hours. Tolerance index was calculated as per formula given by by Maiti et al. [17]. 


\subsection{Measuring Leaf Area and Stomatal Parameters}

Paired primary leaves from six days old seedlings were collected. Leaf area was determined by using a mm graph paper. By counting the number of large, medium and small squares, the total area of the individual primary leaf was determined. Upper and lower epidermal layers were peeled off from 6 days old primary leaf whose area was already drawn over graph paper. The epidermal peels were stained with $0.1 \%$ saffranin from which stomatal frequency and stomatal index were determined with the help of Karlzeiss microscope. Stomatal frequency was determined as equal to number of stomata per sq. $\mathrm{cm}$. of leaf area. Stomatal index was calculated as per formula $\mathrm{S} /(\mathrm{S}+\mathrm{E}) \times$ 100 ; where, $S=$ Number of stomata per unit area, $E=$ Number of epidermal cells in the same unit area.

\subsection{Determination of RWLC}

Relative leaf water content (RLWC), defined as water content of tissue as a percentage of that of the fully turgid tissue. Fresh leaf samples were cut into small pieces and their fresh weight was taken. Subsequently, they were immersed in double distilled water at $28^{\circ} \mathrm{C} \pm 1^{\circ} \mathrm{C}$ for four hours and their turgid weight was recorded. These leaves were then dried at $80^{\circ} \mathrm{C} \pm 1^{\circ} \mathrm{C}$ in a hot air oven for 48 hours and dry weight was taken. RLWC was determined by employing the formula given by Barrs and Weatherley [18].

\subsection{Chlorophyll Content and Chlorophyll Stability Index (CSI)}

Chlorophylls were extracted by $80 \%(\mathrm{v} / \mathrm{v})$ acetone following percolation method of Hiscox and Israelstam [19] and determined spectrophotometrically at wavelengths 645 $\mathrm{nm}$ and $663 \mathrm{~nm}$, after the chlorophyll extraction had been completed as indicated by discoloration of leaf samples and the amount of chlorophyll a, chlorophyll $b$ and total chlorophyll were calculated according to Arnon's [20] formula. Chlorophyll stability index was estimated according the formula given by Sairam [21].

\subsection{Malondialdehyde Content (Lipid Peroxidation)}

The level of lipid peroxidation was measured following the thiobarbituric acid (TBA) test which determines malondialdehyde (MDA) as an end product of lipid peroxidation [22]. Freshly harvested seedling sample $(0.5 \mathrm{~g})$ was homogenized in $4 \mathrm{ml}$ of $1 \%$ trichloroacetic acid (TCA). The homogenate was centrifuged at 10,000 rpm for $10 \mathrm{~min}$. The supernatant was added to $1.0 \mathrm{ml}$ of $0.5 \%$ (w:v) thiobarbituric acid (TBA) in 20\% TCA. The mixture was incubated at $95^{\circ} \mathrm{C}$ for $30 \mathrm{~min}$ and then quickly cooled in an ice bath. After centrifugation at 10,000 rpm for $10 \mathrm{~min}$, the absorbance of the supernatant was recorded at $532 \mathrm{~nm}$ using a UV-VIS spectrophotometer. The value for non-specific absorption at $600 \mathrm{~nm}$ was subtracted from the value recorded at $532 \mathrm{~nm}$. The MDATBA complex (pink pigment) content was calculated using its extinction coefficient of $155 \mathrm{mM}^{-1} \mathrm{~cm}^{-1}$ and expressed as nmol (MDA) $\mathrm{g}^{-1}$ fresh weight.

\subsection{Proline Content}

Proline content in the leaf was estimated according to the method of Bates et al. [23] 
(1973). The leaf samples were homogenized with $3 \%$ sulphosalicylic acid and centrifuged at 10,000 rpm for 15 minutes. Two $\mathrm{ml}$ of the extract were mixed with $2 \mathrm{ml}$ glacial acetic acid and $2 \mathrm{ml}$ ninhydrin solution. The mixture was heated in a boiling water bath for one hour and the reaction was terminated by placing the mixture tube in ice bath. Four $\mathrm{ml}$ of toluene was added to each tube, shaken well and the absorbance of the separated toluene layer was read at $520 \mathrm{~nm}$ in a Spectronic 20 Genesys spectrophotometer and proline content ( $\mu \mathrm{g} \cdot \mathrm{g}^{-1}$ fresh weight) was determined using a standard curve obtained with known concentrations of proline.

\subsection{Total Phenol Content}

Total phenol was extracted through homogenizing $100 \mathrm{mg}$ leaf samples with $20 \mathrm{ml}$ methanol, transferring the homogenate to $100 \mathrm{ml}$ conical flask, refluxing on boiling water bath for $30 \mathrm{~min}$ and centrifuging at 10,000 rpm for 15 minutes followed by cooling. Total phenol content in the extract was determined according to Swain and Hillis [24]. The solution absorbency was determined after reaction with Folin-Denis reagent and addition of $2 \mathrm{ml}$ saturated $\mathrm{Na}_{2} \mathrm{CO}_{3}$ at $650 \mathrm{~nm}$ in a Spectronic 20 Genesys spectrophotometer. Total phenol content was estimated in catechol equivalent comparing with a standard curve obtained with catechol.

\subsection{Ascorbic Acid Content}

Ascorbic acid was isolated by extraction with 6\% trichloroacetic acid from $100 \mathrm{mg}$ leaf tissue, following the method described by Mukherjee and Choudhuri [25]. Four ml of the extract was mixed with $2 \mathrm{ml}$ of $2 \%$ (w/v) 2, 4 dinitrophenylhydrazine, followed by the addition of 1 drop of $10 \%(\mathrm{w} / \mathrm{v})$ thiourea solution (in $70 \%$ ethanol). The mixture was boiled for 15 minutes in a water bath and after cooling at room temperature, $5 \mathrm{ml}$ of $80 \%(\mathrm{v} / \mathrm{v}) \mathrm{H}_{2} \mathrm{SO}_{4}$ was added to the mixture at $0^{\circ} \mathrm{C}$. The absorbance of the solution containing the hydrazine complex was read at $530 \mathrm{rpm}$ in a Spectronic 20 Genesys spectrophotometer. The concentration of ascorbic acid was calculated from a standard curve prepared with known concentrations of ascorbic acid.

\subsection{Hydrogen Peroxide}

Hydrogen peroxide $\left(\mathrm{H}_{2} \mathrm{O}_{2}\right)$ was estimated with titanium reagent as described by Teranishi et al. [26]. Plant sample (0.5 g) was homogenized in $10 \mathrm{ml}$ of cold acetone. The homogenate was filtered through Whatman No. 1 filter paper. To the filtrate, $4 \mathrm{ml}$ of titanium reagent was added, followed by addition of $5 \mathrm{ml}$ ammonium solution to precipitate the peroxide-titanium complex. The reaction mixture was centrifuged at 10,000 rpm for 10 minutes. Supernatant was discarded and the precipitate was dissolved in 10 $\mathrm{ml}$ of $2 \mathrm{M} \mathrm{H}_{2} \mathrm{SO}_{4}$. It was re-centrifuged to remove the undisclosed material and absorbance was recorded at $415 \mathrm{~nm}$ against a reagent blank. The concentration of hydrogen peroxide $\left(\mathrm{H}_{2} \mathrm{O}_{2}\right)$ was determined by referring to a standard curve made from known concentrations of $\mathrm{H}_{2} \mathrm{O}_{2}$.

All morho-physiological and biochemical parameters were expressed as the means of 
three replicates and significant differences between treatments were analyzed using analysis of variance (ANOVA) following the method as described by Panse and Sukhatme [27]. All the statistical analyses were done by using XLSTAT. For correlation analysis, the index values (viz. tolerance index, chlorophyll stability index) under control were considered as 1.00 since index was the ratio of treatment value to respective control value for a particular cultivar.

\section{Results and Discussion}

Data presented in Table 1 revealed that seedling growth in terms of fresh and dry weight of different parts of the seedlings of both K-851 and PDM-84-139 declined with increasing moisture stresses in most of the cases with little exception in root dry weight at some of the tested external water potentials in case of K-851. Out of the two cultivars, K-851 was found to be least affected in terms dry weight of seedling by decreasing external water potential than PDM-84-139. Adverse effects of water stress on fresh and dry weight of seedling might be due to lower dry matter partitioning between cotyledons and embryonic axis under simulated water stress conditions during seedling

Table 1. Changes in dry weight (data expressed as $\mathrm{mg}$ seedling ${ }^{-1}$ ) of leaf, stem and root of six days old seedlings of two mungbean cultivars grown under different water potentials.

\begin{tabular}{|c|c|c|c|c|c|}
\hline Cultivars & Water potentials (bars) & Leaf & Stem & Root & Total dry weight \\
\hline \multirow{5}{*}{$\mathrm{K}-851$} & 0.0 & 4.3 & 12.8 & 3.4 & 20.5 \\
\hline & -1.0 & $\begin{array}{c}3.9 \\
-(9.30)\end{array}$ & $\begin{array}{c}11.7 \\
-(8.59)\end{array}$ & $\begin{array}{c}4.6 \\
+(35.2)\end{array}$ & $\begin{array}{c}20.2 \\
-(1.46)\end{array}$ \\
\hline & -2.0 & $\begin{array}{c}4.0 \\
-(6.97)\end{array}$ & $\begin{array}{c}12.4 \\
-(3.12)\end{array}$ & $\begin{array}{c}3.6 \\
+(5.88)\end{array}$ & $\begin{array}{c}20 \\
-(2.44)\end{array}$ \\
\hline & -3.0 & $\begin{array}{c}4.3 \\
-(0.00)\end{array}$ & $\begin{array}{c}10.6 \\
-(17.2)\end{array}$ & $\begin{array}{c}3.3 \\
-(2.94)\end{array}$ & $\begin{array}{c}18.2 \\
-(11.2)\end{array}$ \\
\hline & -4.0 & $\begin{array}{c}3.0 \\
-(30.2)\end{array}$ & $\begin{array}{c}9.0 \\
-(29.7)\end{array}$ & $\begin{array}{c}3.7 \\
+(8.82)\end{array}$ & $\begin{array}{c}15.7 \\
-(23.4)\end{array}$ \\
\hline \multirow{5}{*}{ PDM 84-139 } & 0.0 & 4.6 & 10.4 & 3.6 & 18.6 \\
\hline & -1.0 & $\begin{array}{c}3.8 \\
-(17.3)\end{array}$ & $\begin{array}{c}9.6 \\
-(7.69)\end{array}$ & $\begin{array}{c}3.2 \\
-(11.1)\end{array}$ & $\begin{array}{c}16.6 \\
-(10.7)\end{array}$ \\
\hline & -2.0 & $\begin{array}{c}3.6 \\
-(21.7)\end{array}$ & $\begin{array}{c}9.8 \\
-(5.77)\end{array}$ & $\begin{array}{c}3.0 \\
-(16.7)\end{array}$ & $\begin{array}{c}16.4 \\
-(11.8)\end{array}$ \\
\hline & -3.0 & $\begin{array}{c}3.4 \\
-(26.1)\end{array}$ & $\begin{array}{c}8.4 \\
-(19.2)\end{array}$ & $\begin{array}{c}3.3 \\
-(8.33)\end{array}$ & $\begin{array}{c}15.1 \\
-(18.8)\end{array}$ \\
\hline & -4.0 & $\begin{array}{c}2.4 \\
-(47.8)\end{array}$ & $\begin{array}{c}6.8 \\
-(34.6)\end{array}$ & $\begin{array}{c}3.2 \\
-(11.1)\end{array}$ & $\begin{array}{c}12.4 \\
-(33.3)\end{array}$ \\
\hline \multirow{2}{*}{ Variety (V) } & S.Em $( \pm)$ & 0.0049 & 0.0099 & 0.0260 & 0.0418 \\
\hline & C.D. (5\%) & 0.0145 & 0.0289 & 0.077 & 0.123 \\
\hline \multirow{2}{*}{ Treatment $(\mathrm{T})$} & S.Em $( \pm)$ & 0.0079 & 0.0160 & 0.0401 & 0.0661 \\
\hline & C.D. $(5 \%)$ & 0.0233 & 0.0472 & 0.118 & 0.196 \\
\hline \multirow{2}{*}{$\begin{array}{l}\text { Interaction } \\
\quad(\mathrm{V} \times \mathrm{T})\end{array}$} & $\operatorname{S.Em}( \pm)$ & 0.0113 & 0.0229 & 0.0575 & 0.0937 \\
\hline & C.D. $(5 \%)$ & 0.0334 & 0.0676 & 0.170 & 0.277 \\
\hline
\end{tabular}

Data in parentheses indicate per cent increase $(+)$ or decrease $(-)$ over control. 
growth. Thakur and Rai [28] reported a significant decline in fresh and dry weight of maize seedlings with decreasing external moisture potential. This was further confirmed by Baalbaki et al. [29] in wheat and De et al. [30] in two Vigna species. Maximum value of drought tolerance index was found in cv. K-851 in comparison to cv. PDM 84-139 under any of the respective water potential (Figure 1). The findings of significant variability among the cultivars in respect of tolerance indices coincide with the reports of Maiti et al. [17].

Leaf area was found to decline with increasing moisture stress in both the mungbean cultivars (Table 2). The cultivar K 851 showed higher leaf area as compared to PDM 84-139 in all the external water potentials tested. Although a higher percentage of reduction in leaf area over control in K 851 in comparison to PDM 84-139 under mod

Table 2. Effect of different moisture stresses on leaf area $\left(\mathrm{cm}^{2}\right)$, relative leaf water content (\%), stomatal frequency and stomatal index and of six days old seedlings of two mungbean cultivars.

\begin{tabular}{|c|c|c|c|c|c|c|c|}
\hline \multirow{2}{*}{ Cultivars } & \multirow[t]{2}{*}{$\begin{array}{l}\text { Water potentials } \\
\text { (bars) }\end{array}$} & \multirow[t]{2}{*}{$\begin{array}{l}\text { Leaf area } \\
\left(\mathrm{cm}^{2}\right)\end{array}$} & \multirow{2}{*}{$\begin{array}{l}\text { RLWC } \\
(\%)\end{array}$} & \multicolumn{2}{|c|}{ Stomatal frequency } & \multicolumn{2}{|c|}{ Stomatal index } \\
\hline & & & & Upper & Lower & Upper & Lower \\
\hline \multirow{5}{*}{ K-851 } & 0.0 & $\begin{array}{c}2.320 \\
-\end{array}$ & 76.38 & $\begin{array}{l}28.728 \\
(5.358)\end{array}$ & $\begin{array}{l}45.144 \\
(6.718)\end{array}$ & $\begin{array}{c}25.51 \\
(5.050)\end{array}$ & $\begin{array}{c}29.55 \\
(5.436)\end{array}$ \\
\hline & -1.0 & $\begin{array}{c}1.433 \\
-38.23^{*}\end{array}$ & 76.00 & $\begin{array}{l}22.700 \\
(4.762)\end{array}$ & $\begin{array}{l}33.748 \\
(5.808)\end{array}$ & $\begin{array}{c}17.55 \\
(4.188)\end{array}$ & $\begin{array}{c}28.21 \\
(5.311)\end{array}$ \\
\hline & -2.0 & $\begin{array}{c}0.843 \\
-63.60^{*}\end{array}$ & 73.40 & $\begin{array}{l}25.075 \\
(5.006)\end{array}$ & $\begin{array}{l}34.199 \\
(5.847)\end{array}$ & $\begin{array}{c}20.21 \\
(4.495)\end{array}$ & $\begin{array}{c}30.69 \\
(5.540)\end{array}$ \\
\hline & -3.0 & $\begin{array}{c}0.738 \\
-68.19^{*}\end{array}$ & 66.10 & $\begin{array}{l}24.624 \\
(4.899)\end{array}$ & $\begin{array}{l}25.075 \\
(5.006)\end{array}$ & $\begin{array}{c}23.02 \\
(4.797)\end{array}$ & $\begin{array}{c}28.27 \\
(5.317)\end{array}$ \\
\hline & -4.0 & $\begin{array}{c}0.505 \\
-78.23^{*}\end{array}$ & 61.81 & $\begin{array}{l}23.707 \\
(4.867)\end{array}$ & $\begin{array}{l}21.887 \\
(4.676)\end{array}$ & $\begin{array}{c}20.34 \\
(4.509)\end{array}$ & $\begin{array}{c}28.48 \\
(5.336)\end{array}$ \\
\hline \multirow{5}{*}{ PDM-84-139 } & 0.0 & $\begin{array}{c}1.218 \\
-\end{array}$ & 74.56 & $\begin{array}{l}26.908 \\
(5.186)\end{array}$ & $\begin{array}{l}30.547 \\
(5.526)\end{array}$ & $\begin{array}{c}21.77 \\
(4.665)\end{array}$ & $\begin{array}{c}25.26 \\
(5.025)\end{array}$ \\
\hline & -1.0 & $\begin{array}{c}0.805 \\
-33.91^{\star}\end{array}$ & 70.59 & $\begin{array}{l}30.096 \\
(5.485)\end{array}$ & $\begin{array}{l}28.728 \\
(5.358)\end{array}$ & $\begin{array}{c}25.36 \\
(5.035)\end{array}$ & $\begin{array}{c}29.44 \\
(5.425)\end{array}$ \\
\hline & -2.0 & $\begin{array}{c}0.513 \\
-57.88^{\star}\end{array}$ & 70.00 & $\begin{array}{l}20.971 \\
(4.577)\end{array}$ & $\begin{array}{l}26.908 \\
(5.186)\end{array}$ & $\begin{array}{c}21.13 \\
(4.535)\end{array}$ & $\begin{array}{c}31.79 \\
(5.638)\end{array}$ \\
\hline & -3.0 & $\begin{array}{c}0.328 \\
-73.07^{\star}\end{array}$ & 60.78 & $\begin{array}{l}20.971 \\
(4.577)\end{array}$ & $\begin{array}{l}25.540 \\
(5.0520\end{array}$ & $\begin{array}{c}18.73 \\
(4.327)\end{array}$ & $\begin{array}{c}31.34 \\
(5.598)\end{array}$ \\
\hline & -4.0 & $\begin{array}{c}0.255 \\
-79.06^{*}\end{array}$ & 57.69 & $\begin{array}{l}20.068 \\
(4.477)\end{array}$ & $\begin{array}{l}26.443 \\
(5.141)\end{array}$ & $\begin{array}{c}18.15 \\
(4.259)\end{array}$ & $\begin{array}{c}31.76 \\
(5.635)\end{array}$ \\
\hline \multirow{2}{*}{$\begin{array}{l}\text { Variety } \\
\text { (V) }\end{array}$} & S.Em $( \pm)$ & 0.0219 & 0.6145 & 0.0452 & 0.0388 & 0.266 & 0.0203 \\
\hline & C.D. $(5 \%)$ & 0.065 & 1.816 & n.s. & 0.115 & n.s. & 0.060 \\
\hline \multirow{2}{*}{$\begin{array}{l}\text { Treatment } \\
\qquad(\mathrm{T})\end{array}$} & S.Em $( \pm)$ & 0.0347 & 0.9716 & 0.0714 & 0.0614 & 0.0420 & 0.0320 \\
\hline & C.D. $(5 \%)$ & 0.102 & 2.872 & 0.211 & 0.181 & 0.124 & 0.095 \\
\hline \multirow{2}{*}{$\begin{array}{l}\text { Interaction } \\
(\mathrm{V} \times \mathrm{T})\end{array}$} & S.Em $( \pm)$ & 0.0491 & 1.3741 & 0.1010 & 0.0868 & 0.0594 & 0.0453 \\
\hline & C.D. $(5 \%)$ & 0.145 & n.s. & 0.298 & 0.256 & 0.175 & 0.134 \\
\hline
\end{tabular}

Asterisked $\left(^{*}\right)$ data indicate per cent increase $(+)$ or decrease $(-)$ over control, and data in parentheses indicate square root transformed values, n.s. Non significant. 


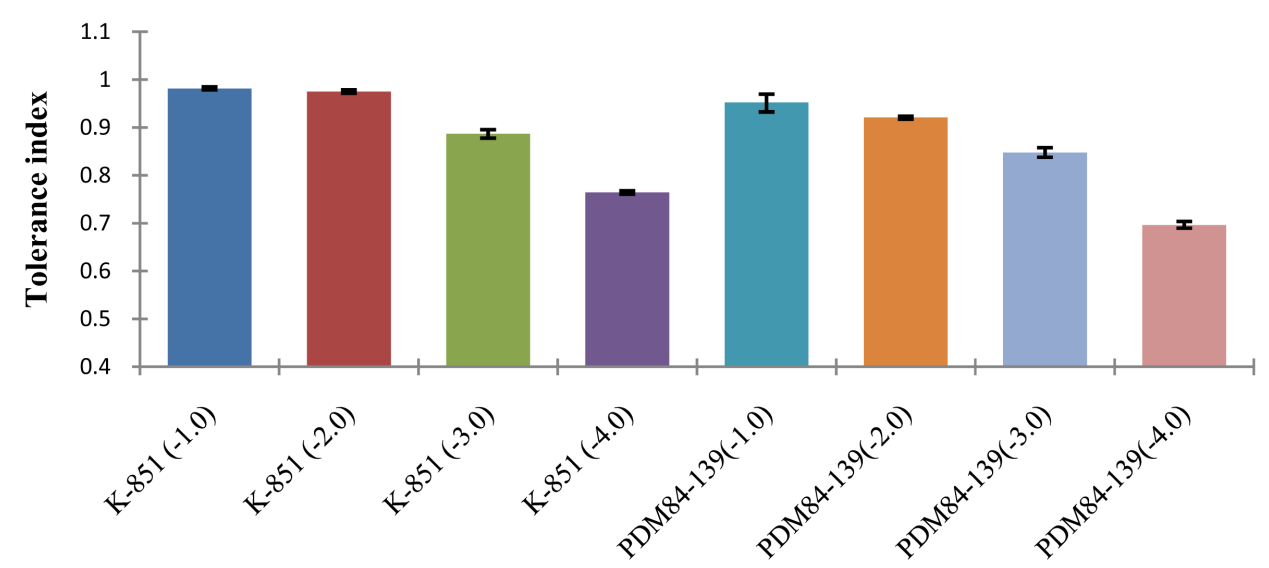

Cultivar (water potential)

Figure 1. Tolerance indices ( \pm SD of three replicates) of K-851 (drought tolerant) \& PDM-84-139 (drought susceptible) under different moisture stresses.

erate moisture stresses (i.e. -1.0 and -2.0 bars) was noticed, but at higher moisture stresses (i.e. -3.0 and -4.0 bars) PDM 84-139 was found to have higher reduction in leaf area over control than $\mathrm{K} 851$. The decrease in leaf area with increasing moisture stresses might be attributed to less elongation and enlargement of cells coupled with lower photosynthetic activity [31]. It is because, leaf area manifests function of cell expansion, which is again depended upon turgidity of cells. Many researchers reported that water stress treatment brought about significant reduction in leaf area development [32] [33]. Higher leaf area of K 851 under various water potential treatments than PDM 84-139 indicated comparatively higher tolerance level of $\mathrm{K} 851$ to water stress conditions. Lower value of stomatal frequency in K-851 compared to other cultivar with respective and increasing magnitude of water stress might indicate its better inherent compliance to resist the stress situation.

At particular water potential, higher RLWC is an indication of drought tolerance through osmoregulation. Drought resistant plants are likely to be less sensitive to changes in external water potential with a relatively small decrease in relative water content than plants which are more susceptible to drought [34].

It is evident from Table 2 that relative leaf water content (RLWC) of both cultivars decreased significantly over control as the external water potential was lowered. However, the cultivar K 851 showed higher RLWC in comparison to the cultivar PDM 84-139 in control as well as in all of the given external water potential treatments. Percent reduction in RLWC over control was found to be more in PDM 84-139 than K 851. Thus higher RLWC of K 851 at a particular level of water stress indicated that $\mathrm{K}$ 851 had more tolerance to drought than PDM 84-139. The differences in RLWC between the two cultivars might be attributed to the differences in their survival under drought stress conditions [32].

Stomatal frequency or the number of stomata per unit leaf area for upper as well as lower surface of leaves was also found to decrease along with the decreasing moisture 
potential for both the varieties (Table 2). The cultivar K-851 was found to contain higher stomatal frequency in most of the cases compared to PDM-84-139. However the stomatal index of primary leaf of 6 days old mungbean seedling of both varieties did not follow any pattern with increase in moisture stress. It was evident that K-851 maintained a lower stomatal index values in the lower surface of leaf at highest level of moisture stress than PDM 84-139.

A steady decreasing pattern in chlorophyll $a$, chlorophyll b and total chlorophyll contents with the increasing moisture stresses in both the cultivars was noticed (Table 3). It was further observed that total chlorophyll content of two cultivars differed significantly from each other and the cultivar K 851 was found to have higher levels of chlorophyll at all the water potential treatments than PDM 84-139. It is evident from the data that water stress increased chlorophyll a/b ratio in both the cultivars and $\mathrm{K} 851$ was found to maintain lower chlorophyll a/b ratio than PDM 84-139 at all the external water potentials tested. The results also revealed that chlorophyll stability index (CSI) declined with lowering external water potential in the cultivars. Out of the two cultivars tested, K 851 was observed to have greater CSI values as compared to PDM 84-139 at all the moisture potential treatments. The decrease in total chlorophyll contents could be typical symptom under drought stress and it may be attributed to the destruct-

Table 3. Changes in chlorophyll-a, chlorophyll-b, total chlorophyll, chlorophyll-a/b ratio and chlorophyll stability index (CSI) in the 6 days old seedlings of two mungbean cultivars grown under different osmotic potentials (data expressed as $\mathrm{mg} \mathrm{g}^{-1}$ fresh weight).

\begin{tabular}{|c|c|c|c|c|c|c|}
\hline Cultivars & Water potentials (bars) & Chl-a & Chl-b & Total chl & $\mathrm{Chl}-\mathrm{a} / \mathrm{b}$ & CSI \\
\hline \multirow{5}{*}{$\mathrm{K}-851$} & 0.0 & 1.965 & 0.791 & 2.755 & 2.484 & - \\
\hline & -1.0 & 1.925 & 0.721 & 2.644 & 2.674 & 0.959 \\
\hline & -2.0 & 1.863 & 0.719 & 2.583 & 2.591 & 0.937 \\
\hline & -3.0 & 1.618 & 0.594 & 2.212 & 2.723 & 0.802 \\
\hline & -4.0 & 1.399 & 0.512 & 1.851 & 2.732 & 0.671 \\
\hline \multirow{5}{*}{ PDM-84-139 } & 0.0 & 1.431 & 0.504 & 1.935 & 2.839 & - \\
\hline & -1.0 & 1.296 & 0.445 & 1.741 & 2.912 & 0.899 \\
\hline & -2.0 & 1.165 & 0.379 & 1.544 & 3.074 & 0.797 \\
\hline & -3.0 & 0.967 & 0.310 & 1.227 & 3.119 & 0.634 \\
\hline & -4.0 & 0.798 & 0.251 & 1.049 & 3.179 & 0.542 \\
\hline \multirow{2}{*}{$\begin{array}{l}\text { Variety } \\
(\mathrm{V})\end{array}$} & S.Em $( \pm)$ & 0.0168 & 0.0054 & 0.0119 & 0.0810 & 0.0029 \\
\hline & C.D. $(5 \%)$ & 0.050 & 0.0160 & 0.035 & 0.240 & 0.0087 \\
\hline \multirow{2}{*}{$\begin{array}{l}\text { Treatment } \\
\quad(\mathrm{T})\end{array}$} & S.Em $( \pm)$ & 0.0265 & 0.0086 & 0.0189 & 0.1283 & 0.0041 \\
\hline & C.D. (5\%) & 0.078 & 0.0254 & 0.056 & n.s. & 0.0122 \\
\hline \multirow{2}{*}{$\begin{array}{l}\text { Interaction } \\
\quad(\mathrm{V} \times \mathrm{T})\end{array}$} & $\operatorname{S.Em}( \pm)$ & 0.0375 & 0.0121 & 0.0267 & 0.1814 & 0.0058 \\
\hline & C.D. (5\%) & n.s. & 0.0358 & 0.079 & n.s. & 0.0174 \\
\hline
\end{tabular}

n.s.-Non significant. 
tion of fine structure of the chloroplasts and/or instability of the pigment protein complex [9]. It might also be due to increase in chlorophyllase activity under water stress conditions [35]. The results of decreasing chlorophyll content with the rise in osmotic stress were observed earlier [36] [37]. Higher chlorophyll content in K 851 than PDM 84 - 139 under osmotic stress conditions might be due to differences in their tolerance level [38]. Increasing chlorophyll $\mathrm{a} / \mathrm{b}$ ratio under water stress might be attributed to lower destruction of chlorophyll a than chlorophyll b under such stress. Decreasing chlorophyll stability index (CSI) with increasing stresses might be due to premature senescence of leaves [39]. Higher values of CSI in K 851 in comparison to PDM 84-139 indicated the comparatively higher tolerance of $\mathrm{K} 851$ to drought which again might have bearing on photosynthesis and ultimately producing higher yield.

Data presented in Table 4 showed that proline content increased with decreasing water potential at all stages of observation irrespective of cultivars tested. The results indicated that phenols content increased with increasing stress levels in both the cultivars. The data also revealed that phenol content in K 851 was higher than PDM 84-139 particularly at later stages. The cultivar K 851 was found to maintain relatively higher

Table 4. Ascorbic acid (mg. $\mathrm{g}^{-1}$ fresh weight), phenol ( $\mathrm{mg} \cdot \mathrm{g}^{-1}$ fresh weight), proline ( $\mu \mathrm{g} \cdot \mathrm{g}^{-1}$ fresh weight), MDA (nmol. $\mathrm{g}^{-1}$ fresh weight) and $\mathrm{H}_{2} \mathrm{O}_{2}\left(\mu \mathrm{mol} \cdot \mathrm{g}^{-1}\right.$ fresh weight) content in leaves of 6 days old mungbean seedlings grown under different water potentials.

\begin{tabular}{|c|c|c|c|c|c|c|}
\hline Cultivars & $\begin{array}{l}\text { Water potentials } \\
\text { (bars) }\end{array}$ & $\begin{array}{l}\text { Ascorbic } \\
\text { acid }\end{array}$ & Phenol & Proline & MDA content & $\mathrm{H}_{2} \mathrm{O}_{2}$ \\
\hline \multirow{5}{*}{ K- 851} & 0.0 & 2.00 & 1.900 & 114 & 142.78 & 2.72 \\
\hline & -1.0 & 1.85 & 2.450 & 202 & 256.55 & 3.89 \\
\hline & -2.0 & 1.52 & 2.571 & 567 & 345.67 & 4.25 \\
\hline & -3.0 & 1.36 & 3.100 & 685 & 363.17 & 4.62 \\
\hline & -4.0 & 1.08 & 3.000 & 743 & 368.46 & 6.18 \\
\hline \multirow{5}{*}{ PDM-84-139 } & 0.0 & 2.00 & 1.650 & 47 & 150.91 & 2.59 \\
\hline & -1.0 & 1.84 & 2.138 & 77 & 272.16 & 4.51 \\
\hline & -2.0 & 1.44 & 2.225 & 144 & 386.78 & 5.26 \\
\hline & -3.0 & 1.16 & 2.857 & 187 & 418.34 & 6.38 \\
\hline & -4.0 & 0.82 & 2.642 & 252 & 465.55 & 6.93 \\
\hline \multirow{2}{*}{ Variety (V) } & S.Em $( \pm)$ & 0.0096 & 0.0092 & 1.8511 & 2.2467 & 0.0173 \\
\hline & C.D. (5\%) & 0.028 & 0.0272 & 5.471 & 6.641 & 0.051 \\
\hline \multirow{2}{*}{ Treatment (T) } & S.Em $( \pm)$ & 0.0152 & 0.0146 & 2.9269 & 3.5524 & 0.0274 \\
\hline & C.D. (5\%) & 0.045 & 0.0432 & 8.651 & 10.450 & 0.081 \\
\hline \multirow{2}{*}{ Interaction $(\mathrm{V} \times \mathrm{T})$} & S.Em $( \pm)$ & 0.0214 & 0.0206 & 4.1392 & 5.0238 & 0.0387 \\
\hline & C.D. $(5 \%)$ & 0.063 & n.s. & 12.234 & 14.849 & 0.114 \\
\hline
\end{tabular}

n.s. - Non significant. 
proline as well as phenol content as compared to PDM 84-139 in respective water potential treatments and stages of seedling development. The findings of higher proline accumulation in K 851 than PDM 84-139 might indicate the differences in their survival under drought stress conditions as proline is considered to be involved in adaptation mechanisms under drought stress. Apart from their osmoregulatory role, proline has protective function for enzymes in the cytoplasm through binding water to the proteins and thus maintaining their hydration. Proline accumulation in stressed plants was reported by Naidu et al. [32] and Anaytullah et al. [40]. Furthermore, Sivakumar et al. [41] reported that proline could be used as biochemical marker for drought tolerance.

Ascorbic acid contents in both the cultivars were decreased with increasing moisture stress (Table 4). K 851 was found to have higher ascorbic acid content as compared to PDM 84-139 in most of the cases under respective water potential treatments. Hydrogen peroxide $\left(\mathrm{H}_{2} \mathrm{O}_{2}\right)$ contents were found to increase in both cultivars with decreasing moisture potentials (Table 4). When cultivars were compared, higher accumulation of $\mathrm{H}_{2} \mathrm{O}_{2}$ was observed in PDM-84-139. The decline in ascorbic acid content due to water stress might be ascribed to a rise in ascorbic acid oxidase activity, which causes oxidation of ascorbic acid. The decline in ascorbic acid content might also be correlated with increase in hydrogen peroxide content under water stress [42], since ascorbic acid is associated with hydrogen peroxide scavenging via ascorbate peroxidase-glutathione reductase linked reactions. Water stress induced reduction in ascorbic acid content was reported by Sairam and Srivastava [43] in wheat, where it was also noticed that ascorbic acid content in tolerant genotypes of wheat was higher than susceptible ones under water stress.

It was found that MDA content followed an increasing trend under increasing magnitude of water stress in both cultivars (Table 4). However, the increase in MDA content was found to be higher in PDM-84-139 compared to K-851 in all the cases. Toxic active oxygen species determine metabolic alternations in cellular membrane system as a consequence of the peroxidation of the lipid layer of the membrane [44]. Increased lipid peroxidation as a result of oxidative stress and consequently cell membrane injury were reported by various workers [43] [45].

Increase in phenolic content could be due to increase in phenylalanine-ammonialyase (PAL) activity during water stress, as PAL is the key enzyme involved in the synthesis of phenolic compounds via phenylpropanoid pathway [46]. Higher accumulation of phenols in K 851 suggests its function as better cellular adaptive mechanism for preventing sub-cellular damages during stress. Accumulation of phenol in plants under biotic and abiotic stresses constitutes a part of cellular solutes and provides a reducing environment to the system [47]. But present study clearly indicates that phenols may play an adaptive role under stress but it would not be considered as major factor for tolerance.

\section{Correlation Analysis}

Simple correlation analysis among the various physiological and biochemical parame- 
ters in mungbean under water stress revealed positive correlation of tolerance index (TI) with ascorbic acid, CSI, leaf area, RLWC, stomatal frequency (lower) and negative correlation with MDA content and hydrogen peroxide content (Table 5). Higher correlation value of TI with both CSI and RLWC proves that CSI and RLWC play very important function to impart tolerance through sustaining chlorophyll status and leaf water balance, respectively under water stress [32] [38]. The most prominent finding was the negative correlation between phenol content and tolerance index. The MDA (lipid peroxidation) and $\mathrm{H}_{2} \mathrm{O}_{2}$ content have strikingly shown maximum numbers of significant association in the correlation analysis. Hence the present study clearly indicates that free radical mediated lipid peroxidation as the central cause of drought injury. Bor et al. [48] reported that lipid peroxidation might be considered as an indicator of the extent of oxidative damage under stress. Drought stress affects many physiological processes of plants due to accumulation of reactive oxygen species (ROS) like superoxide radical $\left(\mathrm{O}^{-}\right)$, hydrogen peroxide $\left(\mathrm{H}_{2} \mathrm{O}_{2}\right)$, hydroxyl radical $\left(\mathrm{OH}^{-}\right)$etc. [49]. Tolerances to drought stress in plants have also been reported to be associated with an increase in activity of antioxidant system to protect against ROS mediated damages [50]. These two leaf parameters might be effective physiological indicators for screening of drought susceptibility.

Table 5. Simple correlation matrix (Pearson) among different morpho-physiological and biochemical parameters in leaves of mungbean under different moisture potentials.

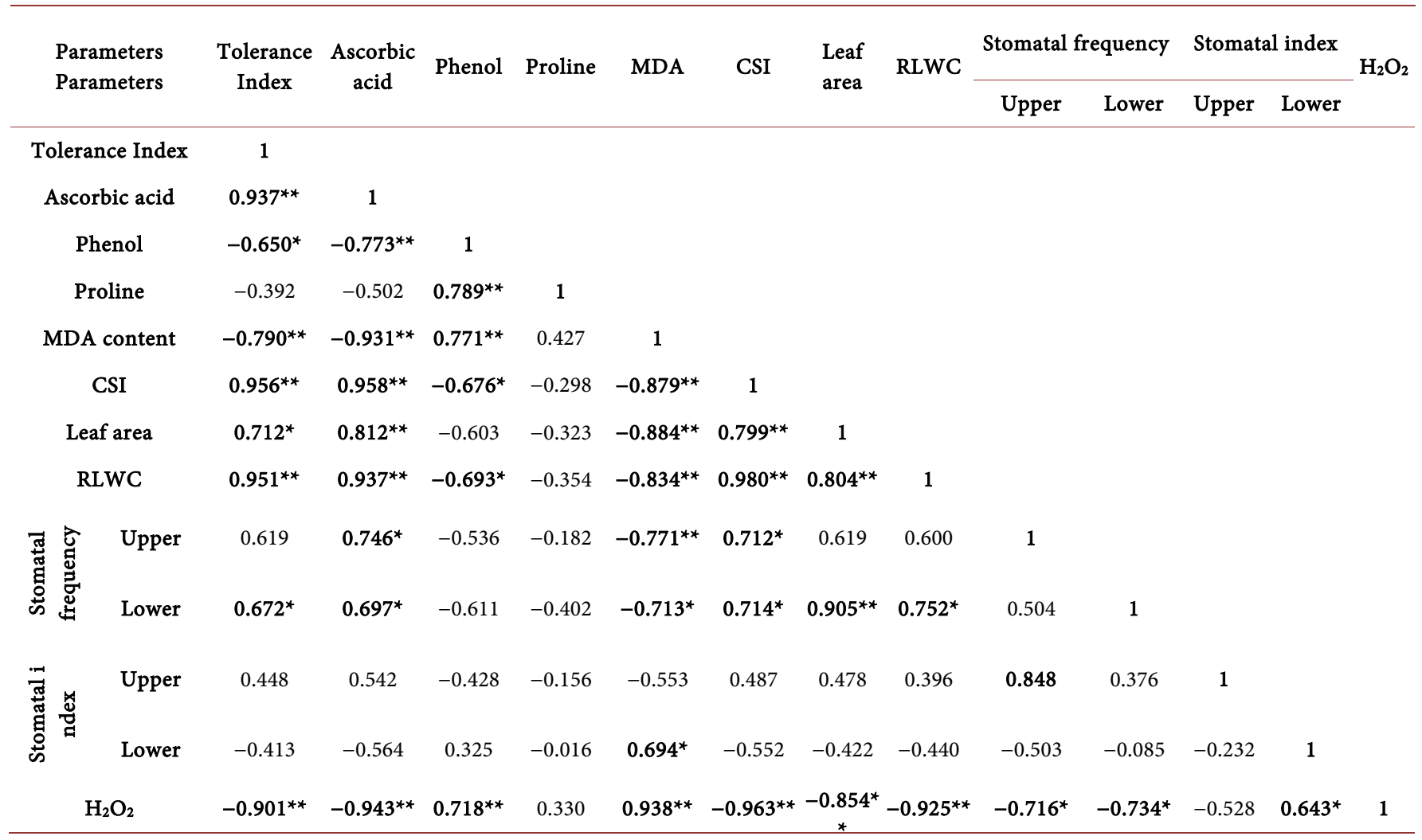

Data marked as $\left(^{*}\right)$ and $\left(^{*}\right)$ are significant at $p<0.05$ and $p<0.01$ respectively. Where, MDA $=$ malondialdehyde content, CSI $=$ chlorophyll stability index, RLWC $=$ relative leaf water content, $\mathrm{H}_{2} \mathrm{O}_{2}=$ hydrogen peroxide content. 


\section{Conclusion}

Lack of accurate screening indicator is a limiting factor to develop drought tolerant mungbean cultivars and also a constraint for mungbean productivity. Though several researchers have been in constant research in identifying several physiological markers and incorporating them through breeding in several cultivars, success is very meagre as most of these traits involve multifaceted physiological paradigms. Water stress has an adverse effect on morph-physiological characters of leaves of this crop. However, the magnitude of growth retardation and injury caused by water stress vary significantly among the cultivars. K 851 showed greater tolerance to drought which seemed to be due to better leaf water balance, chlorophyll stability as well as higher accumulation of proline, phenols and potent antioxidant like ascorbic acid. From the correlation study, it is concluded that lipid peroxidation and $\mathrm{H}_{2} \mathrm{O}_{2}$ content might be considered as potent physiological markers for drought response study in mungbean at its early seedling stage. The genotype with drought tolerance traits may be used in future genetic manipulation programmes to establish drought tolerance in this crop.

\section{Acknowledgements}

It is gratefully acknowledged the award of University Research Scholarship by Bidhan Chandra Krishi Viswavidyalaya, Kalyani, Nadia, West Bengal, India to the first author during this study.

\section{Author Contribution Statement}

P.D. performed the experimental works. P.B. prepared the English text and A.K.B. interpreted data. The idea, concept, calculations and all other contributions came from both authors.

\section{Conflicts of Interest}

The authors declare that they do not have any competing interests.

\section{References}

[1] Bohnert, H.J. and Sheveleva, E. (1998) Plant Stress Adaptations-Making Metabolism Move. Current Opinion in Plant Biology, 1, 267-274. http://dx.doi.org/10.1016/S1369-5266(98)80115-5

[2] Mahajan, S. and Tuteja, N. (2005) Cold, Salinity and Drought Stresses: An Overview. Biochem Biophys, 444, 139-158. http://dx.doi.org/10.1016/j.abb.2005.10.018

[3] Allahmoradi, P., Ghobadi, M. and Taherabadi, S. (2011) Physiological Aspects of Mungbean in Response to Drought Stress. International Conference on Food Engineering and Biotechnology, 9, 272-275.

[4] Patade, V.Y., Maya, K. and Zakwan, A. (2011) Seed Priming Mediated Germination Improvement and Tolerance to Subsequent Exposure to Cold and Salt Stress in Capsicum. Research Journal of Seed Science, 4, 125-136. http://dx.doi.org/10.3923/rjss.2011.125.136

[5] Postel, S.L. (2000) Entering an Era of Water Scarcity. The Challenges Ahead. Ecological Application, 10, 941-948. 


\section{http://dx.doi.org/10.1890/1051-0761(2000)010[0941:EAEOWS]2.0.CO;2}

[6] Kramer, P.J. and Boyer, J.S. (1997) Water Relation in Plants and Soils. Academic Press, San Diego, Calif.

[7] Chaves, M.M., Flexas, J. and Pinheiro, C. (2009) Photosynthesis under Drought and Salt Stress: Regulation Mechanisms from Whole Plant to Cell. Annals of Botany, 103, 551-560. http://dx.doi.org/10.1093/aob/mcn125

[8] Nahar, K., Hasanuzzaman, M., Alam, Md.M. and Fujita, M. (2015) Glutathion-Induced Drought Stress Tolerance in Mungbean: Coordinated Roles of the Antioxidant Defence and Methyglyoxal Detoxification Systems. AoB Plants, 7, plv069. http://dx.doi.org/10.1093/aobpla/plv069

[9] Kaur, V., Singh, S. and Behl, R.K. (2016) Heat and Drought Tolerance in Wheat: Integration of Physiological and Genetic Platforms for Better Performance under Stress. Journal of Crop Breeding and Genetics, 2, 1-14.

[10] Bogale, A., Tesfaye, K. and Geleto, T. (2011) Morphological and Physiological Attributes Associated to Drought Tolerance of Ethiopian Durum Wheat Genotypes under Water Deficit Condition. Journal of Biodiversity and Environmental Sciences, 1, 22-36.

[11] Jallel, C.A., Manivannan, P., Wahid, A., Farook, M., Somasundaram, R. and Panneerselvam, R. (2009) Drought Stress in Plants: A Review on Morphological Characteristics and Pigments Compositions. International Journal of Agriculture and Biology, 11, 100-105.

[12] Razmjoo, K., Heidarizahed, P. and Sabzalian, M.R. (2008) Effect and Salinity and Drought Stresses on Growth Parameters and Essential Oil Content of Matricaria Chamomile. International Journal of Agriculture and Biology, 10, 451-454.

[13] Giancarla, V., Madosa, E., Şumalan, R., Adriana, C. and Cerasela, P. (2012) Evaluation of Some Indirect Indices to Identify Drought Tolerance in Barley. Journal of Horticulture, Forestry and Biotechnology, 16, 239-241.

[14] Dutta, P. and Bera, A.K. (2008) Screening of Mungbean Genotypes for Drought Tolerance. Legume Research, 31, 145-148.

[15] Michel, B.E. and Kaufmann, M.R. (1973) The Osmotic Potential of Polyethylene Glycol 6000. Plant Physiology, 51, 914-916. http://dx.doi.org/10.1104/pp.51.5.914

[16] Nandi, S. and Bera, A.K. (1995) Effect of Mercury and Manganese on Seed Germination and Seedling Growth in Black Gram. Seed Research, 23, 125-128.

[17] Maiti, R.K., de la Rosa-Ibarra, M. and Sandoval, N.D. (1994) Genotypic Variability in Glossy Sorghum Lines for Resistance to Drought, Salinity and Temperature Stress at the Seedling Stage. Plant Physiology, 143, 241-244. http://dx.doi.org/10.1016/S0176-1617(11)81694-9

[18] Barrs, H.D. and Weatherley, P.E. (1962) A Re-Examination of the Relative Turgidity Techniques for Estimating Water Deficits in Leaves. Australian Journal of Biological Sciences, 15, 413-428. http://dx.doi.org/10.1071/BI9620413

[19] Hiscox, J.D. and Israelstam, G.F. (1978) A Method for the Extraction of Chlorophyll from Leaf Tissue without Maceration. Canadian Journal of Botany, 57, 1332-1334. http://dx.doi.org/10.1139/b79-163

[20] Arnon, D.I. (1949) Copper Enzymes in Isolated Chloroplasts. Polyphenol Oxidase in Beta Vulgaris. Plant Physiology, 24, 1-15. http://dx.doi.org/10.1104/pp.24.1.1

[21] Sairam, R.K. (1994) Effect of Moisture Stress on Physiological Activities of Two Contrasting Wheat Genotypes. Indian Journal of Experimental Biology, 32, 594-597.

[22] Hodges, D.M., DeLong, J.M., Forney, C.F. and Prange, R.K. (1999) Improving the Thiobar- 
bituric Acid-Reactive Substances Assay for Estimating Lipid Peroxidation in Plant Tissues Containing Anthocyanine and other Interfering Compounds. Planta, 207, 604-611. http://dx.doi.org/10.1007/s004250050524

[23] Bates, L.S., Waldren, R.P. and Teare, I.D. (1973) Rapid Determination of Free Proline for Water Stress Studies. Plant and Soil, 39, 205-207. http://dx.doi.org/10.1007/BF00018060

[24] Swain, J. and Hillis, W.E. (1959) The Phenolic Constitutents of Prunus domestica. I. The Quantitative Analysis of Phenolic Constituents. Journal of the Science of Food and Agriculture, 10, 63-68. http://dx.doi.org/10.1002/jsfa.2740100110

[25] Mukherjee, S.P. and Choudhuri, M.A. (1983) Implications of Water Stress Induced Changes in the Levels of Endogenous Ascorbic Acid and Hydrogen Peroxide in Vigna Seedlings. Physiologia Plantarum, 58, 166-170. http://dx.doi.org/10.1111/j.1399-3054.1983.tb04162.x

[26] Teranishi, Y., Tanaka, A., Osumi, M. and Fukui, S. (1974) Catalase Activity of hyDrocarbon Utilizing Candida Yeast. Agricultural Biological Chemistry, 38, 1213-1216. http://dx.doi.org/10.1080/00021369.1974.10861301

[27] Panse, V.G. and Sukhatme, P.V. (1989) Statistical Methods for Agricultural Workers. ICAR, New Delhi.

[28] Thakur, P.S. and Rai, V.K. (1984) Water Stress Effects on Maize: Growth Responses of Two Differentially Drought Sensitive Maize Cultivars during Early Stage of Growth. Indian Journal of Ecology, 11, 92-98.

[29] Baalbaki, R.Z., Zurayk, R.A., Blaik, M.M. and Talhouk, S.N. (1999) Germination and Seedling Development of Drought Tolerant and Susceptible Wheat under Moisture Stress. Seed Science and Technology, 27, 291-302.

[30] De, R., Sinhababu, A., Banerjee, A. and Kar, R.K. (2005) Effect of Water Stress on Seed Germination and Seedling Growth in Mungbean and Blackgram. Crop Research, 29, 148155.

[31] Boyer, J.C. (1983) Sub-Cellular Mechanism of Plant Response to Low Water Potential. Agricultural Water Management, 7, 239-248.

http://dx.doi.org/10.1016/0378-3774(83)90087-2

[32] Naidu, T.C.M., Raju, N. and Narayanan, A. (2001) Screening of Drought Tolerance in Green Gram (Vigna radiata L. Wilczek) Genotypes under Receding Soil Moisture. Indian Journal of Plant Physiology, 6, 197-201.

[33] Deshmukh, D.V., Mhase, L.B. and Jamadagni, B.M. (2004) Evaluation of Chickpea Genotypes for Drought Tolerance. Indian Journal of Pulses Research, 17, 47-49.

[34] Virk, S.S. and Singh, O.S. (1990) Osmotic Properties of Drought Stressed Periwinkle (Chatharanthus roseus) Genotypes. Annals of Botany, 66, 23-30.

[35] Reddy, M.P. and Vora, A.B. (1986) Salinity Induced Changes in Pigment Composition and Chlorophyllase Activity of Wheat. Indian Journal of Plant Physiology, 29, 331-334.

[36] Reddy, A.M., Shankhdhar, D. and Shankhdhar, S.C. (2007) Physiological Characterization of Rice Genotypes under Periodic Water Stress. Indian Journal of Plant Physiology, 12, 8993.

[37] Hayatu, M. and Mukhtar, F.B. (2010) Physiological Responses of Some Drought Resistant Cowpea Genotypes (Vigna unguiculata L Walp) to Water Stress. Bayero Journal of Pure and Applied Sciences, 3, 69-75.

[38] Kumari, M., Dass, S., Vimala, Y. and Arora, P. (2004) Physiological Parameters Governing Drought Tolerance in Maize. Indian Journal of Plant Physiology, 9, 203-207.

[39] Dutta, P. and Bera, A.K. (2014) Effect of $\mathrm{NaCl}$ Salinity on Seed Germination and Seedling 
Growth of Mungbean Cultivars. Legume Research, 37, 161-164.

http://dx.doi.org/10.5958/j.0976-0571.37.2.024

[40] Anaytullah, Bose, B. and Yadav, R.S. (2007) PEG Induced Moisture Stress: Screening for Drought Tolerance in Rice. Indian Journal of Plant Physiology, 12, 189-192.

[41] Sivakumar, V., Ramchandran, K., Ravichandran, V. and Vangamud, M. (1998) Effect of Drought Hardening on Proline Content of the Tree Seedlings. Annals of Plant Physiology, 12, 82-84.

[42] Dutta, P. and Bera, A.K. (2007) Oxidative Stress and Changes in the Activity of Active Oxygen Scavenging Enzymes of Mungbean Seedling Subjected to Water Stress. Indian Journal of Plant Physiology, 12, 199-210.

[43] Sairam, R.K. and Srivastava, G.C. (2001) Water Stress Tolerance of Wheat (Triticum aestivum L.): Variations in Hydrogen Peroxide Accumulation and Antioxidant Activity in Tolerant and Susceptible Genotypes. Journal of Agronomy and Crop Science, 186, 63-70. http://dx.doi.org/10.1046/j.1439-037x.2001.00461.x

[44] Ranieri, A., Lencioni, L., Schenone, G. and Franco, G. (1993) Glutathione-Ascorbic Acid Cycle Pump in Plants Grown under Polluted Air in Open Top Chambers. Plant Physiology, 142, 286-290. http://dx.doi.org/10.1016/S0176-1617(11)80424-4

[45] Sairam, R.K., Deshmukh, P.S. and Saxena, D.C. (1998) Role of Antioxidant System in Wheat Genotypes' Tolerance to Water Stress. Biologia Plantarum, 41, 384-394. http://dx.doi.org/10.1023/A:1001898310321

[46] Hahlbrock, K. and Scheel, D. (1989) Physiology and Molecular Biology of Phenylpropanoid Metabolism. Annual Review of Plant Physiology and Plant Molecular Biology, 40, 347-369. http://dx.doi.org/10.1146/annurev.pp.40.060189.002023

[47] Das, N., Misra, M. and Misra, A.N. (1990) Sodium Chloride Salt Stress Induced Metabolic Changes in Callus Cultures of Pearlmillet (Pennisetum americanum L. Leeke): Free Solute Accumulation. Plant Physiology, 137, 244-246. http://dx.doi.org/10.1016/S0176-1617(11)80090-8

[48] Bor, M., Ozdemir, F. and Turkur, I. (2003) The Effect of Salt Stress on Lipid Peroxidation and Antioxidants in Leaves of Sugarbeet (Beta vulgaris L.) and Wildbeat (Beta meritima L.). Plant Science, 164, 77-84. http://dx.doi.org/10.1016/S0168-9452(02)00338-2

[49] Ding, Z.S., Zhou, B.Y., Sun, X.F. and Zhao, M. (2012) High Light Tolerance Is Enhanced by Overexpressed PEPC in Rice under Drought Stress. Acta Agronomica Sinica, 38, 285-292. http://dx.doi.org/10.1016/S1875-2780(11)60106-5

[50] Silva, E.N., Ribeiro, R.V., Ferreira-Silva, S.L., Vieira, S.A., Ponte, L.F.A. and Silveira, J.A.G. (2012) Coordinate Changes in Photosynthesis, Sugar Accumulation and Antioxidative Enzymes Improve the Performance of Jatropha curcas Plants under Drought Stress. Biomass and Bioenergy, 45, 270-279. http://dx.doi.org/10.1016/j.biombioe.2012.06.009 
Submit or recommend next manuscript to SCIRP and we will provide best service for you:

Accepting pre-submission inquiries through Email, Facebook, LinkedIn, Twitter, etc.

A wide selection of journals (inclusive of 9 subjects, more than 200 journals)

Providing 24-hour high-quality service

User-friendly online submission system

Fair and swift peer-review system

Efficient typesetting and proofreading procedure

Display of the result of downloads and visits, as well as the number of cited articles

Maximum dissemination of your research work

Submit your manuscript at: http://papersubmission.scirp.org/

Or contact ajps@scirp.org 